\title{
Ligatures of the Early Modern Book
}

Jason Scott-Warren

In a series of images exhibited in 2009, from a project entitled 'Last Folio', the photographer Yuri Dojc takes us into a Jewish school in eastern Slovakia that had been closed up since 1943, when its students were removed to the concentration camps. ${ }^{1}$ Dojc's pictures of the school focus on its books, books that have been mouldering for more than six decades and appear to be turning slowly back into wood. Their pages, mildewed and dank, number the years that have passed like rings in a tree. Dojc's lens is preoccupied with paper; with its fragility, its propensity to rip, tear, and burn, with its weight and its lightness. But he also captures its powers of resistance - the solid, ligneous quality that makes it more durable than flesh. Every so often, we catch a glimpse of string or cord, whether it is the noose-like twine that snakes its way around a pile of books, the rough ties pressing on sheaves of paper; or the determined stitching that once held a volume together. As these last folios wait patiently for a death that their readers found long ago, they reveal the book as a thing of paper and string. A few photographs in the series show the achingly silent spaces within which these volumes would have been encountered. These books came together because this was a place that brought people together. Their bare ruined quires testify to their origins in an act of material pulling-together that borders on a social convocation.

In this essay, I want to bring the multiple forms of stringing, tying and binding that constitute the book back into view — to suggest that in its codex form the book is, first and foremost, a ligatured thing — and to suggest that the ligatures of the book are not just material but social. I use the present tense here, although the focus of my attention will be early

\footnotetext{
${ }^{1}$ http://www.lastfolio.com (accessed 11 November 2016); Yuri Dojc and Katya Krausova, Last Folio: Textures of Jewish Life in Slovakia (Bloomington: Indiana University Press, 2011).
} 
modern books, volumes from the first two and a half centuries of print, which are particular striking for the many ways in which they are pulled together. A ligature is, according to the OED, 'anything used in binding or tying; a band, bandage tie'; figuratively it is 'anything binding or uniting; a bond, tie'. ${ }^{2}$ This capacious definition can be applied to describe numerous elements of the book-object. This might mean that it is unhelpfully baggy, allowing us to play fast-and-loose with the evidence to create a facile show of significance. My hope is, on the contrary, that an exploration of the material and metaphorical affordances of the book, viewed as an assemblage of strings and fastenings and filaments, will lead us to a new sense of its physical properties and its distinctiveness as a medium that brought paper and people together.

The most obvious meaning of the word 'ligature' for bibliographers is one that applies to individual pieces of type. A ligature is 'two or more letters joined together', or it is the stroke that connects the letters. ${ }^{3}$ Early print carried over the practice of joining letters from manuscript, both because it was customary and because it helped to solve the practical problem created by the juxtaposition of kerned letters - letters with elements that rose beyond the main body of the typeface. Early printers went to considerable lengths to introduce ligatures. Aldus Manutius stopped the press on numerous occasions during the printing of his 1501 Virgil in order to insert groups of conjoined letters newly supplied to him by his typefounder, Francesco da Bologna. ${ }^{4}$ So heavily ligatured were the fonts that were taken up from manuscript into early print, and so closely aligned were the characters, that they were dubbed textura - the name testifying to the similarity between a written page and a woven

\footnotetext{
${ }^{2}$ Oxford English Dictionary, 'ligature, n.’ 1a. and b.

${ }^{3}$ Michael F. Suarez, S.J., and H. R. Woudhuysen, The Oxford Companion to the Book (Oxford: Oxford University Press, 2010), s.v. 'ligature'.

${ }^{4}$ Randall McLeod, 'The Birth of Italics' (unpublished research paper, read at the Cambridge Centre for Material Texts, 27 June 2014).
} 
cloth, text and textile. ${ }^{5}$ But tied letters died out over the centuries, leaving the minimallyligatured page that we are familiar with today. One modern introduction to typography defines ligatures as 'single characters that represent the two most common overlapping character pairs: fi and fl', although it adds that 'in some faces ... further ligatures, for ffi and ffl, also exist'. ${ }^{6}$ The segregation of the letter in modernity indicates an increasing divergence of print from handwriting, and resonates with larger narratives of alienation that have sprung up around print. For Walter Ong, print is optimized for a new world of silent, individual and instrumental reading. With its evenly-spaced letter-forms, it belongs to 'an insistent world of cold, non-human, facts', whereas '[handwritten] control of space tends to be ornamental, as in calligraphy'. ${ }^{7}$ More recently, the anthropologist Tim Ingold has argued that the ductus or flow of manuscript is entirely absent in printed letters, in which 'no trace remains of the energetic movement of the hands that made them'. ${ }^{8}$ When the hand vanishes, so too does the body. Print is, for Ingold, a kind of disembodied writing.

Such perspectives risk romanticizing late medieval manuscript production, in which ligatures (like contractions) clearly served a practical purpose, speeding up what must occasionally have seemed like impersonal and mechanical forms of scribal labour. They perhaps also neglect the way that early print drew on centuries of refinement to the letterforms (registered most obviously in serifs), which created the rhythmic linkages that turn words into flowing visual units. ${ }^{9}$ Only after print has wrought its transformations do ligatures

\footnotetext{
${ }^{5}$ Suarez and Woudhuysen, Oxford Companion, s.v. 'textura type'; Geoffrey Dowding, An Introduction to the History of Printing Types, $2^{\text {nd }}$ edn (London: British Library, 1998), 4-7.

${ }^{6}$ Phil Baines and Andrew Haslam, Type and Typography (London: Laurence King, 2002), 167. William Savage, A Dictionary of the Art of Printing (London: Longman et al., 1841), s.v. 'Ligatures', reports that only seven ligatures are currently in use, though 'within the last thirty years' seven more were employed to accommodate the long 's'. John Smith, The Printer's Grammar (London: for the editor, 1755), 36-8, acknowledges seventeen 'double letters' but seems keen to banish ligatures altogether.

${ }^{7}$ Walter J. Ong, Orality and Literacy: The Technologizing of the Word, $3^{\text {rd }}$ edition (New York: Routledge, 2012), 122.

${ }^{8}$ Tim Ingold, Lines: A Brief History (London: Routledge, 2007), 138-9.

${ }^{9}$ Malcolm B. Parkes, Pause and Effect: An Introduction to the History of Punctuation in the West (Aldershot: Scolar Press, 1992), 40. For the impact of cursive scribal hands on letter-forms before 1500, see Malcolm B. Parkes, Their Hands Before Our Eyes: A Closer Look at Scribes (Aldershot: Ashgate, 2008), 71-85.
} 
and other flourishes come to seem at once the bearers of personality and the objects of nostalgia. The end-point of this process in the later twentieth century was found in the stark contrast between the plainness of the printed cheque and the illegible graphic flow of the signature that validates it. This is one of the senses in which (as Peter Stallybrass has put it) print invented manuscript, forcing handwritten text into a differential system and robbing it of its normativity. ${ }^{10}$ Even the word 'ligature' bears the traces of this history: although we can find innumerable instances of cursive or ‘joined-up' handwriting —indeed, perhaps because we can find so many instances - the word itself does not seem very useful for describing manuscript, whereas it neatly captures the exceptions that prove the rule of movable type.

While all of this ligaturing was going on in the book's pages, another distinctive regime was in place behind the scenes, in the binding. The stitching that pulls together folded gatherings to make a codex is usually invisible to readers, but it would have been considerably more visible in the early modern period, when books were sold in sheets to be bound at the purchaser's convenience. Samuel Pepys would not have been the only bookbuyer who stayed up 'till late at night' watching his binder working 'with great pleasure'. ${ }^{11}$ Binding was, as Jeffrey Todd Knight has pointed out, potentially a creative act, offering opportunities for appropriation and customization. Books could be split apart, interleaved, or joined together with other titles in ways that transformed their potential usage and meaning. These practices resonated in a culture in which reading and writing were frequently forms of compilation that pulled texts into new material and intellectual relationships. Physical ligatures, acts of binding and rebinding, could be embodied interpretations. $^{12}$

\footnotetext{
${ }^{10}$ Peter Stallybrass, 'Printing and the Manuscript Revolution', in Barbie Zelizer, Explorations in Communication and History (London: Routledge, 2008), ch. 7.

${ }^{11}$ Robert Latham and William Matthews, eds, The Diary of Samuel Pepys, 11 vols (London: G. Bell and Sons, 1970-83), vol. 9, 46.

12 Jeffrey Todd Knight, Bound to Read: Compilations, Collections, and the Making of Renaissance Literature (Philadelphia: University of Pennsylvania Press, 2013); David McKitterick, Print, Manuscript and the Search
} 
Once a book was bound, the labour that went into compiling it and knitting it together might be hidden in the binding. But in the early modern period it might often be more accurate to say that it was not hidden but displaced. For it is striking that, when people came to decorate bindings in this period, they favoured schemes that might be read as meditations on connectedness. This style begins in the strapwork bindings beloved of northern European humanists in the mid sixteenth-century and reaches its apogee in the so-called 'fanfare' bindings developed in the later seventeenth-century. Such bindings, which initially drew their arabesques from Egyptian or Islamic precursors, take lines for a walk in the most dazzling fashion. ${ }^{13}$ The ascription of meaning to pattern is of course fraught with difficulties, but it is tempting to see in the entrelacement of elite binding styles a sublimation of the mundane work of sewing and stitching that is hidden away beneath the binding. Complexly interwoven designs increase what Alfred Gell has called the 'cognitive stickiness' of a surface, turning it into a kind of flypaper for the mind; they also suggest connections between the textual and the textile that are more immediately visible on the embroidered bindings that were popular throughout the later sixteenth and earlier seventeenth centuries. ${ }^{14}$ All this decoration was not just a way of binding a book in; it also bound it out, to other books and other objects. ${ }^{15} \mathrm{~A}$ particular design served both to knit an individual's books together, to connect them via a distinctive style. The same Pepys who sat up watching his binder at work also went to great expense to rebind all his older books, so as 'to make my whole study of the same binding', and to acquire bookshelves that would show the books off to their best advantage. The point

for Order, 1450-1830 (Cambridge: Cambridge University Press, 2003), 48-52; Jason Scott-Warren, 'Reading on the Threshold', in Subha Mukherji, ed., Thinking on the Threshold: The Poetics of Transitive Spaces (London: Anthem Press, 2011), 157-72.

${ }^{13}$ Rosamond E. Mack, Bazaar to Piazza: Islamic Trade and Italian Art, 1300-1600 (Berkeley: University of California Press, 2002), 125-37.

${ }^{14}$ Alfred Gell, Art and Agency: An Anthropological Theory (Oxford: Oxford University Press, 1998), 80-1, 86.

${ }^{15}$ See e.g. Claire Canavan, 'Embroidered Bookbindings in Early Modern England', The New Bookbinder 34 (2014), 13-19; and Mack, Bazaar, 135-7, for the movement of techniques and styles used in bindings to other kinds of leather object. 
of his library was to furnish a room, in his case a closet or study. Everything needed to work together. ${ }^{16}$

Books were not just bound outwards to books and other objects, but also to other people. When Jean Grolier and his contemporaries commissioned their visual celebrations of joined-up thinking, they claimed that they owned the book with their friends. Their bookbindings were stamped with the words 'Jean Grolier et amicorum', 'Tomas Maioli et amicorum', and so on. ${ }^{17}$ So, at the same time as they parade the owner's wealth, these bindings convene a community of friends who (as Erasmus put it) hold all things in common. ${ }^{18}$ Particular binding styles migrated through communities like any fashion. We might speculate that styles and ornaments were shared between friends or family members, as in the bindings of a Bible and a Psalm commentary, now held in different libraries in Oxford, which were bound for two brothers-in-law living in London, probably in the 1570s. ${ }^{19}$ The fact that the same chainlink strapwork design is found on both books might be purely coincidental, based on the unremarkable fact that the two men patronized the same binder. But it might indicate that their tastes were, like their lives, intertwined.

A third form of ligature to which early modern books were subject was the clasp, a remnant of the much more elaborate furniture that protected medieval books, but one which still served a practical purpose in keeping volumes flat and preventing any warping of paper or parchment. ${ }^{20}$ Clasps were usually incised with more or less elaborate decorative designs, and they are prominent in painted and engraved representations of books, which show books

\footnotetext{
${ }^{16}$ Diary of Samuel Pepys, vol. 6, 14; Kate Loveman, 'Books and Sociability: The Case of Samuel Pepys's Library’, Review of English Studies 61 (2010): 214-233. On books as furniture, see Jeffrey Todd Knight, “"Furnished for Action”: Renaissance Books as Furniture’, Book History 12 (2009): 37-73.

${ }^{17}$ G. D. Hobson, 'Et Amicorum', The Library, $5^{\text {th }}$ ser., 4 (1949), 87-99; Mirjam M. Foot, The Henry Davis Gift, 3 vols (London: British Library, 1978-2010) 1, 183-91.

${ }^{18}$ David Wootton, 'Friendship Portrayed: A New Account of Utopia', History Workshop Journal 45 (1998), 2547.

${ }^{19}$ Howard M. Nixon, 'Elizabethan Gold-Tooled Bindings', in Essays in Honour of Victor Scholderer (Mainz: Karl Pressler, 1970), 219-70, p. 256; Bodleian Library, Oxford, Broxb. 29 2; Trinity College, Oxford, K 103.

${ }^{20}$ David Pearson, English Bookbinding Styles, 1450-1800: A Handbook (London: British Library, 2005$), 26$.
} 
stored (as they were) with their fore-edges facing out. ${ }^{21}$ This kind of bookish ligature transforms the tactile engagement with the book. It makes each volume foursquare, a miniature version of the boxes or chests in which books themselves were often stored, and of the closets in which such boxes or chests were kept. ${ }^{22}$ The homology is visible in the trompe l'oeil intarsias in the church of Santa Corona in Vicenza, which repeatedly juxtapose books and boxes, revelling in the perspectival pleasures of their tilted forms. It is also invoked in a story recycled by Protestant polemicists which concerns 'old wife at Venice' who, to vaunt her religiosity, 'caused two great bookes to be made, both of equall bigness', and then locked herself away with them for six days, allegedly to fast and pray. While one of the books was a Bible, the other was 'hollowe within, as a little chist, made in all points like a book, with claspes \& al, which she filled with flat bottles ful of Malmesie, and with good fine Marchpanes, which she her selfe made, of the brawne of Capons and Partridges, with Sugar and Almondes (like a lickerous Ladie)'. ${ }^{23}$ Anticipating the 'dummy books' of the eighteenth and nineteenth centuries, the lady exploits the ability of the codex to function as a deceptive covering, masking contents that directly undercut its spiritual pretensions. ${ }^{24}$

A clasped book was an open-or-shut case. As such it offered a powerful emblem for reading and non-reading. Shakespeare’s Lady Capulet praises Paris to Juliet: 'That book in many's eyes doth share the glory / That in gold clasps locks in the golden story'. ${ }^{25}$ But she is one of the very few people who had a good word to say about the clasped book. The physical fact of clasping was usually taken to signify mental darkness. John Smith, vicar of Clavering in Essex, thought that 'men should weepe to see the Booke of God lye clasped in their

\footnotetext{
${ }^{21}$ For a set of medallion portraits on the clasps of an early seventeenth-century English binding, see Howard M. Nixon, Five Centuries of English Bookbinding (London: Scolar Press, 1978), 64 (cat. 26).

${ }^{22}$ Lena Cowen Orlin, Locating Privacy in Tudor London (Oxford: Oxford University Press, 2007), ch. 8; Lucy Razzall, 'Containers and Containment in Early Modern Literature' (unpublished PhD dissertation, University of Cambridge, 2013); Knight, “"Furnished for Action”, 42-3.

${ }^{23}$ Philips van Marnix van St. Aldegonde, The Bee Hiue of the Romishe Church (London: Thomas Dawson, 1579), D6r.

${ }^{24}$ For the association between dummy books, foodstuffs, and bathos see Leah Price, How to do Things with Books in Victorian Britain (Princeton: Princeton University Press, 2012), 26-8.

${ }^{25}$ William Shakespeare, Romeo and Juliet, ed. Jill Levenson (Oxford: Oxford University Press, 2000), 1.3.93-4.
} 
Churches, and no man (to open it and) expound it to them' ${ }^{26}$ Another churchman, Andrew Willett, set the Old Testament, 'compared to a clasped booke', against the New, 'a booke opened', asserting that 'the knowledge of Christians farre exceedeth the knowledge of the Iewes' ${ }^{27}$ And John Donne preached that the human heart was 'a booke, legible enough, and intelligible in it selfe; but we have so interlined that booke with impertinent knowledge, and so clasped up that booke, for feare of reading our owne history, our owne sins, as that we are the greatest strangers, and the least conversant with the examination of our owne hearts' ${ }^{28}$ Hearts, open and closed, were materialized in bindings that employed heart-shaped clasps, as in an eighteenth-century Bible and Psalter that have been bound 'side-by-side', creating a volume that is 'rather like a cupboard' in its physical structure. ${ }^{29}$ Shakespeare suggests the potential of the clasped book of the heart as an intimate and potentially erotic property when, in Twelfth Night, he has Orsino tell Cesario: 'I have unclasped / To thee the book even of my secret soul' ${ }^{30}$ Like the joins between letters and bindings, book-clasps raise questions about the disposition of the self and its relationships with others.

Equally interesting, though in some respects the poor relation of the clasp, was the tie or book-string. Strings made of coloured silk or leather adorned a huge variety of books in the sixteenth and seventeenth centuries. Like clasps, they rarely survive intact today. Often the remains of ties are visible inside the cover of the book, attached to the boards; sometimes a flash of colour clings to the outsides. Book-strings came in a variety of colours, some of

\footnotetext{
${ }^{26}$ John Smith, Essex Dove (London: George Edwardes, 1629), E2r, citing Revelations 5.4.

${ }^{27}$ Andrew Willett, Synopsis Papismi (London: Thomas Orwin, 1592), D6r, citing Isaiah 29. 11 and Revelations 5.

${ }^{28}$ John Donne, LXXX Sermons (London: Richard Royston, 1640), fol. 3V1v. For the use of clasps in the metaphorical equation between book and heart, see Eric Jager, The Book of the Heart (Chicago: University of Chicago Press, 2000), 143-8.

${ }^{29}$ The Holy Bible (Oxford: Thomas Baskett, 1756), Chetham’s Library, Manchester, shelfmark B.2.90; http://chethamslibrary.blogspot.co.uk/2010/08/some-unusual-bindings.html (accessed 11 November 2016). See also http://finds.org.uk/database/artefacts/record/id/527079, which is one of many clasps registered on the website of the Portable Antiquities Scheme. The furniture of old books is today often found buried in the ground.

${ }^{30}$ William Shakespeare, Twelfth Night, or What You Will, ed. Roger Warren and Stanley Wells (Oxford: Oxford University Press, 1994), 1.4.13-14.
} 
which would have been symbolic. Thomas Dekker imagines Jealousy as a book that 'all our Italian dames, and signiors reade’, 'strung with yellow ribbon' ${ }^{31}$ A copy of John Rainolds' De Romanae ecclesiae idololatria in a contemporary Oxford binding bears the remnants of multicoloured ties, with strands of red, blue, green, orange, yellow and white. ${ }^{32}$ In my own small survey, the most common colour for book-strings seems to have been green, perhaps reinforcing Bruce Smith's sense that green is ‘the generative hue' in Renaissance English culture. $^{33}$ The visual and haptic interest of ties is suggested by Renaissance portraiture. In a wonderful celebration of tactility by Lorenzo Lotto, the Venetian collector Andrea Odoni is shown revelling in the cool sensuality of classical sculpture. But equally available to the hand are a number of scattered coins, also tokens of antiquity, and a book, its black binding and strings setting off the silver of the bosses and gilding of the leaves. ${ }^{34}$ Moroni's portrait of the Bergamasque writer Giovanni Bressani, dated 1562, places a classicizing inkstand centrestage, but it also presents a miniature waterfall of untied, vellum-bound books, suggesting (albeit in rather a showy way) that his books were not for show but for use. ${ }^{35}$ Contrast the same artist's Portrait of a Gentleman in the Uffizi, where the strings are enigmatically halfopen, half-tied; or his rendition of the formidable, worldly-looking Canon Bartolomeo Bonghi, who is caught with his finger in an unlaced book. ${ }^{36}$ These paintings use ties to hint at a sensuous intimacy between the body and the book. They suggest depths—in the personality

\footnotetext{
${ }^{31}$ Thomas Dekker, Penny-wis[e] Pound Foolish (London: Edward Blackmore, 1631), D4v.

${ }^{32}$ Corpus Christi College, Oxford, $\Delta 17$ 20; David Pearson, Oxford Bookbinding 1500-1640 (Oxford: Oxford Bibliographical Society, 2000), 49. I am grateful to David Pearson for this reference.

${ }^{33}$ Bruce R. Smith, The Key of Green: Passion and Perception in Renaissance Culture (Chicago: University of Chicago Press, 2009), 258.

${ }^{34}$ David Alan Brown, Peter Humfrey and Mauro Lucco, Lorenzo Lotto: Rediscovered Master of the Renaissance (New Haven: Yale University Press, 1997), cat. 28.

${ }^{35}$ Dora Thornton, The Scholar in his Study: Ownership and Experience in Renaissance Italy (New Haven: Yale University Press, 1997), frontispiece and plate 75.

${ }^{36}$ Peter Humfrey, Giovanni Battista Moroni: Renaissance Portraits (Fort Worth: Kimbell Art Museum, 2000), cat. 8.
} 
of the sitter, in the experience of reading-whilst making that depth a material proposition: open or closed, laced or unlaced. ${ }^{37}$

Prominent ties are also found in paintings from the British Isles, including a portrait of the Scottish historian and herald Sir James Balfour, in which the brilliant blue bows on one of the volumes on the shelf jostle for attention with the sash that he wears as a herald. ${ }^{38}$ Still more extreme ostentation is found in the portrait of Mrs Clement Edmondes, who parades a copy of her husband's Obseruations vpon Caesars Commentaries (first published in 1604). The wide scarlet ribbons on this copy go beautifully with the plush red velvet of the stool that supports the book; at least one copy of Obseruations survives today with comparable sashes (although these are green, not red), suggesting that the painting's fabric was not entirely fabricated. ${ }^{39}$ Paintings like this one capitalize on the connections between the textile trappings of the book and the material stuffs of clothes and furnishings. A copy of Eikon Basilike, the textual relic of Charles I which became wildly popular across Europe in the wake of the King's execution in 1649, bears unusual black and white ribbons; an earlier owner of the book has added a note suggesting that these might be mourning bands, dressing the book up for a funeral (just as printed elegies often wore black mourning pages). ${ }^{40}$ The most spectacular ties known to me come from another copy of the Eikon, which claims that its oversized light-blue closures are Charles I's garter-ribbons, the ribbons immortalized in Van Dyck's celebrated portrait of the monarch viewed from three angles. (The recent conservation of the book has suggested that, unlike most stories of this kind, this one might actually be true). ${ }^{41}$

\footnotetext{
${ }^{37}$ On the use of silk ties for intimate letters, see Heather Wolfe, “"Neatly sealed, with silk, and Spanish wax or otherwise”: The Practice of Letter-Locking with Silk Floss in Early Modern England', in S. P. Cerasano and Steven W. May, eds, In the Prayse of Writing (London: British Library, 2012), 169-89.

${ }^{38}$ Scottish National Portrait Gallery, PG 1551.

${ }^{39}$ Karen Hearn, ed., Dynasties: Painting in Tudor and Jacobean England 1530-1630 (London: Tate Publishing, 1995), cat. 134; Christies London sale catalogue (30 April 2008), lot 185.

${ }^{40}$ Cambridge University Library, CCD 819.

${ }^{41}$ See http://www.royalcollection.org.uk/conservation/case-study-Eikon; I am grateful to Lucy Razzall for this reference.
} 


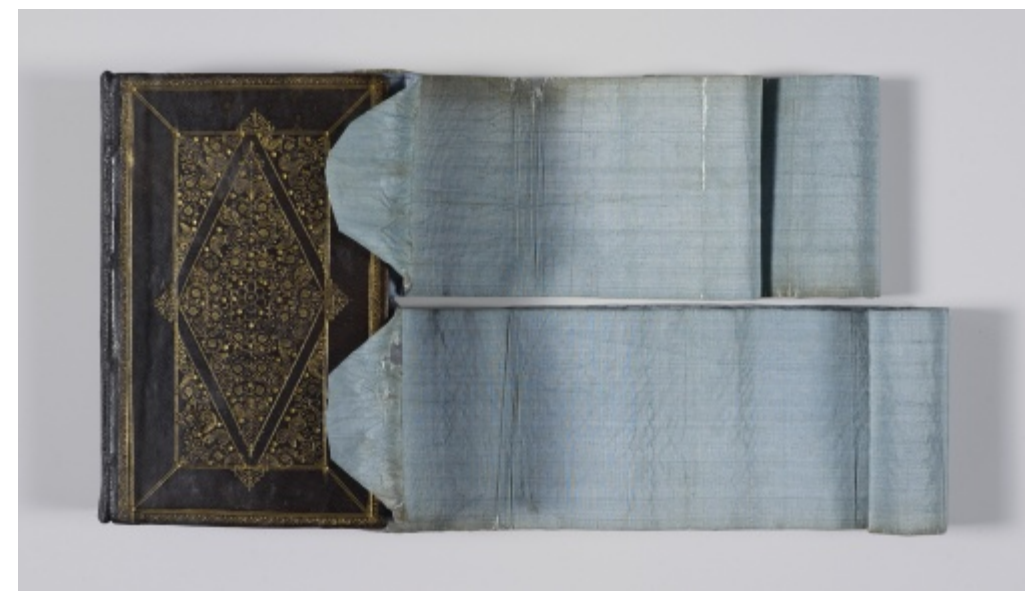

If clasps make a book into a box or chest, ribbons and strings link it with other things — purses, shoes, the multitude of strings or 'points' that were obligatory at a time when outfits were a complex composite, a patchwork of different pieces. ${ }^{42}$ Ties could be a sign of foppishness; a courtier in Beaumont and Fletcher's play The Woman Hater, showing off the furnishings of his study, boasts that 'my book-strings are sutable \& of a reaching colour', while John Earle’s Microcosmographie mocks ‘a meere young Gentleman of the Universitie’ whose 'Studie has commonly handsome Shelues, his Bookes neat Silke strings, which he shewes to his Fathers man, and is loth to vntye or take downe for feare of misplacing' ${ }^{43}$ Henry Peacham's ‘compleat gentleman' would not want to waste money on 'gilding and stringing for ostentation sake, like the prayer bookes of girles and gallants, which are carried to Church but for their outsides'. ${ }^{44}$ But the ostentatious book-tie could also serve godly ends. The protestant martyrologist John Foxe recorded the tale of a merchant named Thomas Sommers who was thrown into the Tower for his possession of books by Martin Luther. The authorities decreed that Sommers should be forced 'to ryde from the Tower into Cheapeside carying a new booke in his hande, and be hanged with bookes rounde about him'. A horse was brought, and officers arrived 'to dresse him with bookes, ... and woulde haue made holes

\footnotetext{
${ }^{42}$ Anne Rosalind Jones and Peter Stallybrass, Renaissance Clothing and the Materials of Memory (Cambridge: Cambridge University Press, 2000), 22-6.

${ }^{43}$ Francis Beaumont and John Fletcher, The Woman Hater (London: John Hodgets, 1607), H4r; John Earle, Micro-cosmographie, or, A Peece of the World Discovered (London: 1628), E8r.

${ }^{44}$ Henry Peacham, The Compleat Gentleman (London: Francis Constable, 1622), I1v.
} 
in hys garment to haue thrust the strynges of the bookes therin, nay sayd Sommers, I haue alwayes loued to goe hansomly in my apparell, \& takyng the bookes and openyng them, he bound them together by the stringes and cast them about his necke (the leaues beyng all open) like a coller, \& beyng on horse backe, rode foremost thorow the streetes till they came aboue the Standard in Cheapeside'. ${ }^{45}$ There (in what seems to be a change of plan) the books were burnt, while Sommers himself was allowed to die in prison. Rewriting the official script for his punishment, Sommers turns a shaming ritual into a bitterly parodic assertion of social status (the conjoined books turning him back into the merchant who 'alwayes loued to goe hansomly in [his] apparell'). He also suggests the power of the open book to figure to foreshadow apocalypse, an idea implicit in Donne's reimagining of the Last Judgment as a time when God's hand 'shall binde vp all our scattered leaues againe, for that Librarie where euery booke shall lie open to one another' ${ }^{46}$

Book-strings are again turned to devout ends in Richard Crashaw's poem accompanying a copy of George Herbert's The Temple given to a gentlewoman, which begins:

Know you faire, on what you looke;

Divinest love lyes in this booke:

Expecting fire from your eyes,

To kindle this his sacrifice.

When your hands unty these strings,

Thinke you have an Angell by th’wings.

One that gladly will bee nigh,

\footnotetext{
45 John Foxe, The Ecclesiasticall History Contaynyng the Actes and Monumentes of Thynges Passed in Euery Kinges Tyme in this Realme (London: John Day, 1570), 3R2r [p. 1381].

${ }^{46}$ John Donne, Devotions upon Emergent Occasions (London: Thomas Iones, 1624), T3r.
} 
To wait upon each morning sigh. ${ }^{47}$

Herbert's shape-poem 'Easter Wings' perhaps already hints at the similarity between the shape of wings and an opened codex. ${ }^{48}$ Crashaw here makes that comparison explicit, turning the book into a fluttering visitant from a higher sphere. The strings allow the gentlewoman to open the book and grasp the angel's 'white plumes' (the book's pages), which will carry her to heaven. The careful Calvinism of 'Easter Wings', which suggests the importance of affliction and grace to salvation, is replaced by a devout eroticism in which the lady's fiery eyes, perfumed sighs and white hand are capable of carrying her 'every day to heaven'. It is unsurprising that such a sensuous poet, whose religiosity is frequently a sublimated eroticism, should be so attuned to the tactile form of the book, its lacings and unlacings.

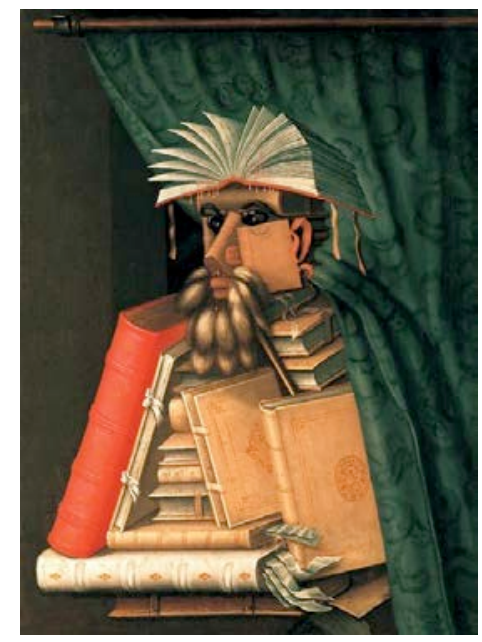

If we are looking for an image to sum up my claim that the early modern book was first and foremost a strung object, we need look no further than the celebrated painting, usually ascribed to Arcimboldo, known as The Librarian. ${ }^{49}$ In confecting a human body out of books, this visual joke relies on the many kinds of ligature that held books together and bound them into the material worlds of their day. Bookmarks suggest a fringe of hair and

\footnotetext{
${ }^{47}$ Richard Crashaw, Steps to the Temple (London: Humphrey Moseley, 1646), E3v.

${ }^{48}$ Random Cloud, 'FIAT fLUX”, in Randall M Leod, ed., Crisis in Editing: Texts of the English Renaissance, AMS (1994), 61-172 (72-3).

${ }^{49}$ Thomas DaCosta Kaufmann, Arcimboldo: Visual Jokes, Natural History, and Still-Life Painting (Chicago:

Chicago University Press, 2009), 63.
} 
extended fingers; silk ties outline the shape of an ear; ties and clasps, done up tight, suggest the numerous interlacings that held clothing in place. The curtain that hangs across the pile of books so as to hint at the shape of a cape suggests the proximity of texts and textiles in numerous elements of the ligatured book. In the fecundity of its invention and its bizarre multiplicity of appendages (what exactly is that beard made from?), the painting speaks of a lost world of tactile engagement with books that always extended beyond their seeming boundaries.

To take Arcimboldo's joke seriously is to entertain the suggestion that early modern readers, writers and librarians were themselves effectively ligatured-prosthetically reconstituted by the connective technologies of the book. That notion is reinforced when we turn to consider some of the ways in which early modern authors dealt with their writings. In Printing a Mediterranean World, Sean Roberts has explored the case of Francesco Berlinghieri, whose Geographia of 1482 was a lavish collection of engraved world maps, accompanied by a visionary poem that carries its reader across the globe. ${ }^{50}$ Roberts reveals the Geographia as a project that aimed at forging connections across the Mediterranean world. As he customized individual copies, turning them into gifts fit for Ottoman sultans and European royals, Berlinghieri was shaping a community of readers linked at once by ties of obligation and by a shared fascination with the knowledge that the book enshrined. Berlinghieri's project becomes, for Roberts, a model for thinking about the physical transmission of ideas: 'The intellectual links between early modern scholars were emphatically material ones, forged not by the transmission of texts but by the movement of books. Books formed a kind of connective tissue that bound authors, readers, statesmen, and

\footnotetext{
${ }^{50}$ Sean Roberts, Printing a Mediterranean World: Florence, Constantinople, and the Renaissance of Geography (Cambridge, MA: Harvard University Press, 2013). For another study that explores the power of the presentation copy to convoke a community of readers, see my Sir John Harington and the Book as Gift (Oxford: Oxford University Press, 2001).
} 
diplomats across great distances'. ${ }^{51}$ In the terms offered by David Trotter in his recent study of the literary impact of twentieth-century communications technologies, the book is a representative rather than a connective medium, but (as he notes) 'no medium ... has remained wholly representational or wholly connective throughout its history' ${ }^{52}$ For the early writer and maker of books, representation and connection were often interdependent spurs to cultural creativity.

Having recast books as connective tissue, we might be inclined to think of the world wide web as the culmination of a certain tendency in book culture-with wires in place of strings, Google Maps as the modern equivalent of the Geographia, and the innumerable routes between servers forming the capillaries through which intellectual life flows. But there are already signs that the material book is reconfiguring itself in order to retain a place in our media landscape. The artists' book tradition has begun to reinvent the codex, opening its architecture to experiment and frequently making a spectacle of its interlacings. ${ }^{53}$ Some of the energy of those artistic investigations is already filtering into mainstream publishing, as in a recent cookery book that bares its strings for all to see. ${ }^{54}$ The challenge from digital is likely to provoke a creative redesign of the book that will give it a new place in our lives, in our clothes and in our domestic interiors.

\footnotetext{
${ }^{51}$ Roberts, Printing, 179.

52 David Trotter, Literature in the First Media Age: Britain Between the Wars (Cambridge, MA: Harvard University Press, 2013), 8.

${ }^{53}$ See the contributions of Jenni Gray, Véronique Van Mol and Fanny Violet to The New Bookbinder 34 (2014), special issue on 'Text, Texture and Con-text'.

${ }^{54}$ Russell Norman, Polpo: A Venetian Cookbook (Of Sorts) (London: Bloomsbury, 2012).
} 